\title{
ÖRGÜN EĞİTIMDE KARŞILAŞILAN ÖĞRENCİ MERKEZLİ SORUNLAR ÜZERİNE BİR DEĞERLENDİRME
}

\author{
AN EVALUATION OF STUDENT-CENTERED PROBLEMS ENCOUNTERED IN \\ FORMAL EDUCATION
}

\section{İsmail DEMİR*}

\begin{abstract}
ÖZ: Bu çalışmada eğitim sahasında karşılaşılan bazı öğrenci merkezli sorunlar ortaya konmuş ve bunlara yönelik çözüm yolları önerilmiștir. Bu sorunların neler olduğunun öteden beri bilinmesine, hatta bu konuda çok ileri adımlar atılmasına rağmen hala bunların toplumca arzu edilen düzeyde çözülüp sağlıklı bir sonuca ulaștırılamadığı düşünülmektedir. Özellikle temel eğitim aşamasında sınıf içerisinde ve dışında yaşanan sorunların başında öğrencilerden kaynaklanan sorunlar gelmektedir. Eğitimin de önemli unsurlarından biri öğrenci olduğundan dolayı, öğrencilerin nitelikleri, eğitimin kalitesi üzerinde oldukça önemli hale gelmiştir. Öğrencilerin önceki yaşantıları, sosyo-ekonomik durumları, kişisel farklılıkları ve okul öncesi dönemde eğitim alıp almadıkları gibi değișkenler de öğrencilerin niteliklerinde belirleyici faktörler arasında sayılabilir. Ayrıca öğrenciler farklı çevreden ve aileden okula geldikleri için hepsi farklı özelliklere sahiptirler. Bu farklılıklardan biri öğrencilerin hazırbulunuşluk düzeyidir. $\mathrm{Bu}$ noktada etkili bir eğitim-öğretim sürecinin gerçekleștirilebilmesi için öğrencilerin her düzeyde sorunlarının özenle dikkate alınması gerekmektedir. $\mathrm{Bu}$ sebeple eğitimde öğrenci hazırbulunuşluğundaki yetersizlik ve eğitmenlerin bu hususa yeterince dikkat etmemesi mühim bir konu haline gelmiștir. Bu bağlamda, bu çalıșma üç farklı başlık altında; Bilișsel Özellikler: (Öğrencilerin okula hazırbulunuşluğu, Olumsuz İletişim), Duyuşsal Özellikler: (Sınav Kaygısı, Dikkat Dağınıklığı, Derse Karşı Önyargılı Olma, Kitap Okuma Alışkanlığının Olmaması, Öğrenciler Arasındaki Rekabet, Öğrencilerin Aileleri ile ilişkileri, Derse Olan İlgisizlik ve Diğer Özellikler: (Akran Zorbalığı ve Öğrencilerin Araç Gereçleri Getirmemesi) incelenmiş ve değerlendirilmiştir.
\end{abstract}

Anahtar Kelimeler: Dikkat dağınıklığı, olumsuz iletişim, önyargı, sınav kaygısı, sınıf içi rekabet.

ABSTRACT: In this study, some student-centered problems encountered in the field of education have been revealed and solutions have been proposed for them. Despite the fact that these problems have been known for a long time and even very advanced steps have been taken in this regard, it is still thought that they have not been resolved at the level desired by the society and achieved a healthy result. Especially in the basic education stage, the problems arising from the students come at the beginning of the problems experienced inside and outside the classroom. Since one of the important elements of education is the student, the qualifications of the students have become very important on the quality of education. Variables such as students' previous experiences, socio-economic status, personal differences and whether they received education in the pre-school period can be counted among the determining factors in students' qualifications. In addition, since students come to school from different backgrounds and families, they all have

* Dr. Öğretim Üyesi - Çanakkale Onsekiz Mart Üniversitesi İlahiyat Fakültesi Felsefe ve Din Bilimler Bölümü / Çanakkale - ismail.demir@comu.edu.tr (Orcid ID: 0000-0001-97561901)

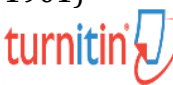

This article was checked by Turnitin 
different characteristics. One of these differences is the level of readiness of the students. At this point, in order to realize an effective education-teaching process, students' problems at all levels should be carefully considered. For this reason, the inadequacy of student readiness in education and the fact that instructors do not pay enough attention to this issue have become an important issue. In this context, this study has been examined and evaluated under three different headings: Cognitive Characteristics (Student Readiness for School, Negative Communication), Affective Characteristics: (Exam Anxiety, Distraction, Prejudice towards the Class, Absence of Reading Habits, Competition Among Students, Students Relationships with their families, Indifference to the Class and Other Characteristics: (Peer Bullying and Students Not Bringing Equipment)

Keywords: Distractibility, exam anxiety, intraclass competition, negative communication, prejudice.

\section{Giriş}

Eğitim, yalnızca kişileri değil aynı zamanda toplumları şekillendirme gücüne de sahip önemli bir süreçtir. Bir yönüyle iyi bir eğitimin, birden fazla unsurun bir araya gelmesiyle oluştuğu düşünülebilir. Bu bütünlük içinde öğrenci- öğretmen ilişkileri, sınıfın fiziki yapısı, materyal ve derse olan ilgi en önemli etmenlerden bazılarıdır. Okul çağında olan bir çocuğun gelişiminde örgün eğitimin katkısı oldukça önemlidir. Çünkü çocuk evden daha çok okulda vakit geçirmektedir. Bu noktada, öğrencilere doğru iletişim kurmayı öğretmenin temel amacı, öğrencilerin kendilerini en iyi şekilde ifade etmelerini ve farklı kaynaklara ulaşarak duygu ve düşüncelerini aktarmalarını sağlamaktır (Karakuş ve Taş, 2007: 4). Bunun yolu da sağlıklı bir iletişimden geçer.

İletişim konusunda başarılı olan bir öğrencinin derslerinde de başarı oranı artar ve derslerini sever. Bu sebeple öğrencilerin kendi arasında ve öğretmenle aralarındaki iletişime ayrıca önem verilmesi gerekmektedir. Bunun, öğrencilerin bilişsel becerilerine de katkısı olduğu kesindir.

Aşağıda, örgün eğitim sürecinde karşılaşılan genel sorunlara yer verilmiştir (Çoban, 2016):
$\checkmark$ Eğitim öğretim programından kaynaklanan sorunlar
$\checkmark$ Öğrenciden kaynaklanan sorunlar
$\checkmark$ Sinıftan kaynaklanan sorunlar
$\checkmark$ İletişimsizlikten kaynaklanan sorunlar
$\checkmark$ Okul yönetimi idareden kaynaklanan sorunlar
$\checkmark$ Aday belirleme sürecinden kaynaklanan sorunlar
$\checkmark$ Fiziki imkânlardan kaynaklanan sorunlar
$\checkmark$ Akademisyenlerden kaynaklanan sorunlar 


\section{Yöntem}

$\mathrm{Bu}$ çalışmada örgün eğitimde karşılaşılan sorunlara dair literatür taraması sonucunda ortaya çıkan sorunlar içerisinden araştırmanın amacı doğrultusunda örgün eğitim ile ilgili karşılaşılan sorunlardan öğrenci merkezli sorunlar ele alınmıștır.

Araştırmada, yazılı ve görsel malzemenin toplanıp incelenmesi olarak tanımlanan, hem nitel hem de nicel araştırmalarda kullanılabilen doküman analizi yöntemi kullanılmıştır. Nitel araştırma yöntemleri arasında yer alan doküman analizi yöntemi, gerek kendi başına, gerekse görüşme ve gözlemle elde edilen verilere destek amacıyla kullanılan bir veri toplama yöntemidir. Bir başka deyişle bu yöntem, araştırılması hedeflenen olgu veya olaylar hakkında bilgi içeren yazılı materyallerin analizini kapsamaktadır. Burada mühim olan, araștırmacının neyi, niçin, nerede ve nasıl arayacağını bilmesi olarak ifade edilmektedir (Sönmez ve Alacapınar, 2013: 84). Bu noktada çalışma konusu ile ilgili uygun görülen yazılı doküman ve belgeler incelenmiş, analizi yapılmış, tartışılmış ve bazı önerilerde bulunulmuştur.

Çalışmada, örgün eğitimde 'Öğrenciden Kaynaklanan Sorunlar' detaylı şekilde ele alınacak ve her bir sorun için öneride bulunulacaktır.

$\mathrm{Bu}$ bağlamda konu üç başlık altında (Bilişsel Özelliklerden Kaynaklanan Sorunlar, Duyuşsal Özelliklerden Kaynaklanan Sorunlar ve Diğer Sorunlar) incelenecektir.

\section{Amaç}

Çalışmanın amacı örgün eğitimde karşılaşılan öğrenci merkezli sorunların ve bu sorunların sebep ve sonuç durumlarının değerlendirilmesidir. Bu çalışmanın etkili bir çalışma olabilmesi için ebeveynlerin ve öğretmenlerin sınıf içerisinde ve dışarıda istenmeyen tüm davranışlarının yalnızca öğrenci kaynaklı sorunlar olmadığını, ayırt edici faktörleri sağlıklı analiz etmeleri, sorunların iyi tespit edilip ortaya konması bakımından çok önemlidir. Özellikle temel öğretim aşamasındaki öğrencilerinin okulda kaygı ve korkudan uzak, olumlu bir sınıf ortamında aktiviteler gerçekleştirebilmeleri için en önemli sorumluluğun ebeveynlere ve öğretmenlere düştüğü unutulmamalıdır. Bu noktada çalışma, daha çok temel öğretim seviyesindeki öğrencilerin, kendilerinden kaynaklanan ve istenmeyen davranışlara ilişkin olumsuz durumlarını değerlendirmeyi ve bu davranışlar için çözüm önerisi getirmeyi amaçlamaktadır.

\section{Bilişsel Özellikler}

\section{1. Öğrencilerin Okula Hazır Bulunuşluğu}

Günümüzde eğitim-öğretimde faaliyetleri amaçlanan hedeflere varılamamasından dolayı bazı problemler yaşanmaktadır. $\mathrm{Bu}$ problemlerden birine örnek verecek olursak; öğrencilerin derslere karşı yeterince bilişsel ve duyuşsal hazırbulunuşluk seviyelerinin olmamasıdır. 
"Hazırbulunuşluk; öğrencinin bazı davranış yeterliklerini gerçekleştirebilmesi için gereken, psikolojik ve fizyolojik donanımları içermektedir. Öğrenmeye dayalı davranışların gelişebilmesi için de, organizmanın bilişsel, duyuşsal ve devinişsel düzeyde belirli davranış biçimlerine ve performans düzeylerine kadar çıkmış olması zorunludur" (Topses, 2003: 25). Ayrıca öğretmenin sınıfı iyi idare etmesi de eğitimde başarıyı sağlamak için birinci basamak olarak kabul edilmektedir (Küçükahmet, 2004: 3).

Bugüne kadar yapılan birçok araştırmada (Bekman vd., 2004), sosyal ve ekonomik olarak yetersiz koşullarda eğitim gören öğrencilerin anasınıfı eğitim hizmetleri ya da erken çocukluk programları ile gerekli önlemler alındığında, daha sağlıklı şartlarda yetişen akranları kadar derslerinde başarılı olabildikleri veya onlara yakın bir seviyeye çıkabilecekleri ortaya konmuştur. Bu sorun için geliştirilmesi gereken önerilerden en önemlisi, okul öncesi eğitim programlarında bulunan çeşitli etkinliklerle, özellikle çocuğun dilsel ve bilişsel becerilerini geliştirmektir. Böylelikle çocuklar kendilerini okula hazır hissederler ve okuma-yazma öğrenmeye istekli olurlar. Anasınıfında; araç, gereç ve diğer uyarıcıların yeterli olduğu bir ortamda, okuma ve yazmaya hazırlık hususunda tecrübe kazanan çocukların bu tecrübelerinin gelecek hayatındaki okul başarı durumunu olumlu yönde etkileyeceği şüphesizdir. Birçok ülkede yaşayan çocuklara okula başlamadan önce hazırbulunuşluk testleri yapılmaktadır. Çünkü çocuğun bu süreçte her açıdan olgunlaşmış olması gerekmektedir. Çocuklara eğitim hayatlarına hazır oluş için gerekli donanımlar sağlanmaktadır. Ayrıca birtakım eşitsizlikler yok edilerek okul başarıları artmaktadır. Bu sebeple ilgili alanda daha çok verimliliğin sağlanması ve kalitenin arttırılması için devamlı kendini yenileyen çalışmalar yapılmalıdır.

Yapılan çalışmalara göre ana sınıfına giden çocukların hazırbulunuşluk düzeyleri, oldukça gelişmiştir. Ana sınıfına gitmeyen diğer çocukların ise hazırbulunuşluk düzeylerinin diğerlerine göre daha düşük olduğu gözlemlenmiştir. Bu durumda çocukların okul öncesi ana sınıfına gidebilmesi için teşvik çalışmalarına önem verilmelidir. Burada öğretmenlere düşen görev öğrencinin hazırbulunuşluk düzeyinin neden istenilen ölçüde olmadığını araştırmak ve bu sonuca göre çözüm üretmektir. Öğrencinin hazırbulunuşluk düzeyi yetersiz olduğu zaman sınıf yönetimini de olumsuz anlamda etkilemektedir. Bu durum dolayısıyla öğretmene de yansımaktadır. Bunu kısa sürede aşmanın yolu ise, öğretmen derse gelmeden önce öğrencisinden bir ön hazırlık veya araştırma yapmasını isteyebilir. Böylece derste ne yapacağını bilen çocuk derse biraz daha güdülenmiş olur.

\subsection{Olumsuz İletişim}

İletişim, verilmek istenen mesajın ilgili kişi ya da kişiler tarafından açıkça anlaşılması amacıyla duygu ve düşüncelerin, konuşma, yazı ve 
görsel araçlarla ya da bu dördünün bir arada kullanılmasıyla karşı tarafa iletilmesi olarak tanımlanabilir (Sillars 1995). Diğer taraftan öğrenme ve öğretme ortamlarında, sınıflarda öğrenci-öğretmen ilişkilerini ve bu yönde başarıyı etkileyen unsur ilişkidir. Bu sebeple ilişkilerin iyi düzenlenmesi gerekmektedir. Öğrenci-öğretmen ilişkisine bakılacak olursa, bu tür ilişki birincil bir ilişkidir. Bu sebeple sınıfta karşılıklı, sürdürülebilir ve insancıl bir ilişki geliștirilmelidir. Bu ilişki türü ben-sen ilişkisidir (Demirtaş, 1999).

İletişim, öncelikle eğitimde işlenmesi gerekli görülen en aktif kuraldır. $\mathrm{Bu}$ yüzden, öğretmen sınıfta iletişim için gerekli ortamı hazırlamalı, iletişimi gayesine uygun hale getirmeli, iletişimin belirli sınırlarını belirlemeli ve öğrencileri gerektiği kadar iletişime katmalıdır. İletişim, öğretmen tarafından veya bir başkası tarafından engellenmemelidir. Bu bağlamda öğretmenin sinıfta oluşturduğu ortam çok önemlidir. Öğrencilerin tanınması, imkânlarının bilinmesi, eğitim seviyelerinin belirlenmesi, kendi problemlerinin belirlenmesi, ilgi ve yeteneklerinin belirlenmesi, bilgiyi doğru aktarabilmeleri ve olumlu davranışların kazandırılması yalnızca öğretmenin sınıfta kurduğu doğru iletişim ile olabilir. İletişim ancak öğretmenden öğrenciye ve öğrenciden öğretmene karşıllklı olarak gerçekleşirse faydalı olur. Tek yönlü iletişim sıkıcıdır ve dönüt olmadığı için varılmak istenilen hedefler gerçekleşmez.

Öğretmenin derste sürekli olarak iletişim kontrolünü kendi elinde tutması, öğrencilerin derse ne zaman katılacağına yine öğretmenin karar vermesi ve müzakere konularını yine öğretmenin seçmesi, öğrencilerin derse olan katılımını azaltmakta ve sınıf içerisinde iletişimi olumsuz yönde etkilemektedir. Bu noktada karşılıklı iletişim, eğitim sürecinde oldukça önemlidir. Ayrıca öğretmenin iletişim sürecinde baskıcı bir tutum ve davranış sergilemesi de elbette yanlıș olacaktır. Bunun yerine öğrencinin kendisiyle sağlıklı bir iletişim kurmasını sağlamalı ve demokratik bir tutum göstermelidir. İletişim problemlerini ortadan kaldırmak için şu önerilerde bulunulabilir: Özellikle öğrenciler kendi arasında konuşurken 'lütfen' dilini kullanmalı, sürekli yargılamamalı, eleştirmemeli, alay etmemeli ve lakap takmamalı, herhangi bir konuda bastırılmamalı, rahat soru sorabilmeli, başkasının sözünü yarıda kesmemeli, iletişim kurallarına dikkat etmeli ve sorulan sorunun cevabını dinlemeli, iletişim kurulan kişiyle göz teması kurmalı ve ön yargılı olmaktan kaçınılmalıdır.

\section{Duyuşsal Özellikler}

\subsection{Sinav Kaygisı}

Sınav kaygısı; davranışsal, bilişsel ya da duyuşsal durumlarda duygu olarak herhangi bir değerlendirilmeye yönelik hissedilen ve kişinin performansını ortaya koymasını engelleyen gerginlik olarak tanımlanır (Spielberger, 1972). Kaygının değişik türleri ile sınav kaygısı arasında bir ilişki bulunmaktadır. Üniversiteye giriş sınavına katılan bir grup lise öğrencisi üzerinde gerçekleştirilen bir araștırmaya göre (Palti, 2012) 
öğrencilerin devamlı sınavı düşünmeleri, sınav kaygılarını arttırmaktadır. Ayrıca yapılan bu araştırmada, sürekli kaygı düzeyi düşük ya da yüksek olan öğrencilerin girdikleri bu sınavdan sonra dahi buna benzer kaygı düzeyine sahip oldukları ortaya konmuştur.

Kaygı, kişinin varoluşsal faktörlerinden biri olarak belirdiği gibi çoğu zaman yaşadığı fiziki ve sosyal çevreyle deneyimleri ve etkileşimleri sonucu rastlanan intrapsişik durumları ifade ederken kullanılan bir nosyon olarak da karşımıza çıkmaktadır. Konuyla alakalı yapılan akademik çalışmalarda sınav için gözlemlenen kaygı çeşidinin genel kaygı türlerinden farklı tutularak değerlendirildiği gözlemlenmektedir. Söz konusu çalışmalara göre, bu tür kaygıya psiko-motor üretime yönelik konuşma ve dinleme becerilerinde rastlanmakta, ayrıca burada olumsuz değerlendirilme korkusundan, sınav kaygısından ve iletişim korkusundan kaynaklanan kaygı durumları da söz konusu olabilmektedir. Bu bulgular ışığında öğrencilerin sağlam bir güdülenmeyle eğitim görmeleri adına kaygıdan olumsuz şekilde etkilenmeyecekleri bir sınıf oluşturulması ve eğitim-öğretim stratejisinin bu yönde benimsenmesi gerektiği öngörülebilir. Özellikle temel eğitim aşamasında sınav kaygısını yenmek için birtakım tavsiyelerde bulunulabilir. Örneğin, zamanı doğru planlama. Kaygı, zaman planlaması hususunda düzensizliklere yol açar. Zaman kaybı oluştukça kaygı daha da artar ve çözülemez bir sorun haline gelir. Sınav öncesinde ders konularını yetiştirme telaşına düşerek öğrenci kendini yetersiz hale getirmemeli, günlük yaşam aktivitelerini korumaya özen göstermeli ve günlük zaman planlamasının bunun için faydalı olacağına inanmalıdır.

\subsection{Dikkat Dağınıklığı}

Dikkat dağınıklığı problemi yaşayan öğrenciler, öğretmenlerinin "Çocuğunuz derste dalıp gidiyor" diyerek bahsettikleri öğrencilerdir. Bu öğrencilerin genel olarak okulda yaşadığı sorunlar, evde yaşadığı sorunların benzeridir. Bu öğrenciler derse başlamakta güçlük çekerler, başladığı ödevi bitirmeleri oldukça zaman alır, kolayca adapte olamazlar ve çalışma saatlerini de düzenleyemezler. Dikkat eksikliği çoğunlukla öğrencinin organize olmakta zorluk yaşamasını da beraberinde getirir. Bu durum, öğrencilerin sıklıkla eşyalarını kaybetmesi, unutkanlıklar yaşaması, seslenildiğinde geç cevap vermesi veya cevap vermemesi gibi davranışlarla kendini gösterir. Fakat dikkat eksikliği sorunu yaşayan çocuklar, aslında sevdikleri ve ilgi duydukları şeylere odaklanmakta güçlük yaşamazlar. Örneğin, uzun süre çizgi film izleyebilir ve saatlerce sevdikleri oyunu oynayabilirler. Çünkü burada daha farklı bir mekanizma devreye girmektedir. Ancak öğrenci ödev yapmaya başladığında artık beynin dikkat bozukluğunu tetikleyen bölgenin devreye girmesi gerekmektedir. $\mathrm{Bu}$ da özellikle bu problemin yaşanmasına sebep olur. Bu tip öğrenciler oturdukları yerde devamlı bir hareket halinde olabilir, dersi dinlemek yerine telefonuyla oynayabilir, sürekli yanındaki arkadaşına bir şeyler fısıldayabilir, çevredeki uyaranlara karşı açık olduğundan dolayı ders 
esnasında meydana gelen bir durum kolay şekilde dikkatinin dağılmasına sebep olabilir ve yeniden derse odaklanması için destek gerekebilir. Ayrıca not tutma, dersi dinleme ve planlama yapma gibi çalışma davranışları oldukça zayıftır ve öğretmenin yönergelerini takip etme konusunda güçlükler yaşayabilir. Yani, bir çalışma ya da aktiviteye uzun süre adapte olamazlar, ders notlarını bir araya getirme ve düzenleme gibi planlama becerileri de oldukça zayıftır.

Derslerde dikkat dağınıklığı problemi yaşayan çocuklar için bu problemden kurtulmanın yolları mümkündür. Örneğin, derse başlamadan önce öğrencilerin sunulan konuyu neden öğrenmeleri gerektiği, yani işlevselliği hakkında malumat sahibi olmaları ve ders esnasında sunumla ilgili kümülatif tekrarlar yapmaları konuya daha iyi odaklanmalarını sağlar. Ders esnasında öğretmenin, öğrenciyi gözlemesi ve öğrencinin yakınında bulunmaya özen göstermesi de dikkat dağınıklığı olabildiğince azaltacaktır. Böylece öğretmen, öğrencinin derse karşı daha iyi şekilde odaklanmasını sağlayabilir ve dinleme davranışını daha iyi kontrol edebilir.

\subsection{Derse Karşı Önyargılı Olma}

Önyargı, bireylerde doğuştan bulunan bir duygu değildir. Bireyler bunları zaman içerisinde dil edinme ve sosyalleşme sürecinde aileden, toplumdan ve yaşadıkları çevreden edinirler. Çünkü dil gelişiminin başlamasından itibaren, çocuk sözcüklerle hisleri ilişkilendirerek algılar ve yaşı ilerledikçe bir sözcükle doğrudan ne anlatılmak istendiğini anlamış olur. Evdeki atmosfer ve ailenin eğitim şekli de önyargıların öğrenilmesinde etkilidir. Çocuk bu süreçte ailesiyle, arkadaşlarıyla ve yaşadığı toplumla özdeşleşerek onların tutum-davranışlarıyla beraber önyargılı tutumlarını edinmiş olur. Bu tutumlar genellikle kin, korku, nefret ya da hoşnutsuzluk gibi sert duygularla yüklüdür. Bu şekilde kazanılan önyargılar çocuğun benliğinde yok edilmesi güç ve derin izler bırakırlar. Böylelikle gruplar veya toplumlararası ilişki ve iletişimlerde problemlere rastlanması kaçınılmaz hale gelir (Gencer, 2009: 47). Peki özellikle temel eğitim aşamasında önyargıyı kırmak için ne gibi önlemlerin alınması ya da aktivitelerin yapılması gerekiyor?

Öncelikle, motivasyonu düşük olan öğrencileri işbirlikli çalışma tekniğiyle sürece dahil etmek ve böylelikle süreci daha eğlenceli bir hale getirerek öğrencilerin önyargısını kırmaya yardımcı olmak. Eğitimde istasyon tekniği gibi eğlenceli grup çalışmalarıyla öğrencileri okumayazmaya güdülemek. Akvaryum, rulman ve konuşma halkası, gibi çeşitli konuşma aktiviteleriyle öğrenciler için konuşma alanları üretip bunları faal hâle getirmek. Bunlar arasında en önemli görülen ise çeşitli münazaralar düzenleyip kaygı içinde olan çocukları sürece dahil etmek ve hazırlıklı konuşma alışkanlığının gelişmesine yardımcı olmak suretiyle öğrencilerin önyargısını gidermek mümkün olarak görülmektedir. 


\subsection{Kitap Okuma Alışkanlığının Olmaması}

Türkçe Öğretim Programında (2006) okuma becerisinde hedeflenen davranışlar; okuduğu metni anlama, okuma kurallarını uygulama, okuduğu metni değerlendirme ve okuma alışkanlığı edinerek bilgi ve birikimi geliştirme șeklinde ifade edilmektedir. Göğüş (1983), öğrencilerin güncel yayınları takip ederek onları kavrama, değerlendirme, yorumlama ve sistematik düşünce tarzına ulaşabilmeleri için okuma yetisine sahip olmalarının yanında okuma alışkanlığı edinmelerine vurgu yapmakta, sistematik düşünme kabiliyetine hızlı ve kolay șekilde yalnızca çok okuyan öğrencilerin ulaşabileceği üzerinde durmaktadır. Buna rağmen ülkemizdeki eğitim kurumlarında okuyan öğrenci sayısının artmasına karşı, okuma alışkanlığı edinen öğrenci sayısı istenilen seviyede değildir.

Öğrencilerde okuma alışkanlığının kazandırılması, devamlılı̆̆ı ve pekiştirilmesi hususunda okul, aile, öğretmen ve bunlar dışında birçok önemli etken rol oynamaktadır (İnan, 2005). Öğrencilerin okuma alışkanlığı kazanabilmeleri öncelikle kendi ilgi, yetenek ve isteğine, aile ilişkilerine, ailenin çocuğa iyi örnek olmasına ve çocuklarına uygun bir ortam hazırlamalarına bağlıdır.

Çocuklara okuma becerisinin kazandırılması her ne kadar kolay olsa da bunun alışkanlığa dönüştürülmesi oldukça zordur. Mert'in (2014) belirttiği gibi okuma alışkanlığı kazandırılması uzun bir süreçtir. $\mathrm{Bu}$, henüz ilkokul yıllarında aile, öğretmen, arkadaş ve çevre grubunun çocuğa okuma ortamı sağlamasıyla davranış hâline gelebilmektedir. Dökmen (1994), çocuklarda okuma alışkanlığının kazandırılması için kitapların evvela çocukların ihtiyaçlarını karşılayabilecek tarzda olması gerektiğini belirtmekte ve çocuğun okumaya duyduğu ihtiyaç kadar iştiyak duyacağını, iştiyakı kadar da düzenli bir okur olabileceğini vurgulamaktadır. Ayrıca Dökmen (1994), kitap okuma alışkanlığının kazandırılması hususunda okuma becerilerinin kitaplarla arkadaşlığa dönüşebileceği ve çevreden, öğretmenlerden ve bilhassa arkadaş grubunun davranışlarından modellenerek, okuma alışkanlığının kazanılabileceği üzerinde durmaktadır. Yani okuma alışkanlığının yalnızca öğrenci ile ilgili olmadığı; bu alışkanlığın kazanımında öğrenciyle birlikte ailenin, çevrenin ve okulun da etkili olduğu anlaşılmaktadır. Aynı zamanda okumada hedeflenen amaca ulaşmanın yolu sistemli, programlı ve devamlı bir şekilde okumaktan geçmektedir (Deniz, 2015).

\section{5. Öğrenciler Arasındaki Rekabet}

Rekabetçi bir ortamın bulunduğu sınıflarda öğrenciler ön plana çıkmak için diğer arkadaşlarıyla yarış halindedirler. Bu tür ortamlarda öğretmen, öğretimi düzenleme, doğru cevapları değerlendirme ve materyalleri sağlama gibi yetkilere sahiptir. Rekabetçi bir sınıf ortamında öğrenci motivasyonu bir nebze sağlanıyor gibi gözükse de aslında daha az yetenekli öğrenciler için bu ortam çok uygun olmayabilir. Ancak, işbirlikçi 
sınıf ikliminde öğrencilerin birlikte çalışma becerileri yani, sosyalleşmeleri gelişmektedir.

Clifford (1989), kontrolsüz bir sınıf ortamında yapılan rekabetin çocuklar üzerindeki olumsuz etkilerini şu şekilde ifade etmektedir: Rekabet, dikkat dağıtıcı olabildiği gibi yoğunlaşmayı da azaltabilmektedir. Eğer yapılan bir etkinlik karmaşı ve alıșılmamış bir etkinlik ise, rekabetçi bir durumun performans ve öğrenme için gerekli olan zihinsel süreçlere müdahale etme olasılığı daha da yüksek olmaktadır. Rekabet, ters tepki faaliyetini teşvik edebilmektedir. Öğrencinin, ihtiyacı olan bir arkadaşına sırf yarışmacı olduğu için yardım etmemesi gibi.

Rekabet, dengesiz beceri gelişimine neden olabilir. Ayrıca, hatalı kendilik algısına da yol açabilmektedir. Rekabet eden ve çoğunlukla başarısız olan öğrenciler, kendileri hakkında başarısızlı gibi olumsuz yargılara sahip olabilmektedir. Rekabet, öğrencilerin yetenekleri hakkında yanlış yargılara yol açabilmektedir. Bu tip rekabetçi durumlardan endişe duyan öğrenciler, mevcut yeteneklerinin altında performans gösterebilirler. Diğer yandan rekabet ortamı, adaletsiz uygulamalara ve hileye yol açabilmektedir. Rekabeti önlemek ya da azaltmak için ise ailede ya da sinıf ortamında çocukları kimseyle karşılaştırmamak ve işbirliği yapmaya teşvik ederek eş güdümlü çalışmaya özendirmek gerekmektedir. Öğrencileri, "Hayattaki ödül ve başarı sayısı çok az olduğu için öteki insanlardan daha iyi olman ve bu başarıları kapman gerekir" psikolojisinden kurtarıp, başarıyı kendilerini gerçekleştirebilecekleri işler yaparak duydukları haz ve mutluluk ile değerlendirmeleri gerektiğini benimsetmek gerektirmektedir.

\section{6. Öğrencilerin Aileleri İle İlişkileri}

Çocukta sağlıklı bir kimlik duygusu, yalnızca dengeli, sıcak, samimi ve çocuğa saygı gösterilen bir aile ortamında gelişebilir. Bunun tersine, anne ve babanın sürekli tartışmaları, çocuğun ihmal edilmesi, şiddet ve kötü muamele görmesi, yeterli ilgi ve sevgi bulamaması, çocuklarda kişilik bozukluğunun, uyumsuzluğun ve tepkisel davranışların ortaya çıkmasına sebep olur. Bu konuda çocuklar üzerinde yapılan bir araştırma, ebeveyn baskısının, çocuğun sosyal ve duygusal gelişimini son derece olumsuz etkilediğini ortaya çıkarmıştır (Yavuzer, 2001).

Tüm bunlarla beraber anne-babanın, çocuğun kişilik gelişiminde olduğu gibi, okul başarısı üzerinde de önemli rolü olduğu yadsınamaz bir gerçektir. Çocuğun kişilik özelliklerinin yerleștiği ve hızlı gelişiminin gerçekleştiği ilk çocukluk dönemi de dahil ilerleyen dönemlerde de aile ortamı eğitsel yönden oldukça önemlidir. Ayrıca, ailenin eğitsel durumu da çocuğun okulda öğrendiği bilgileri pekiştirebilir veya köreltebilir (Başaran, 1996).

Diğer taraftan aileler, çocuklarını okula gönderdiklerinde onlardan haklı olarak başarı beklemektedirler. Fakat çocuğun okuldaki başarısı ne şekilde sağlanır?' Başarılı olmasında hangi faktörler önemli rol oynar? Bu 
hususta ailelere düşen yükümlülükler nelerdir? gibi sorulara cevap verebilecek bilgi düzeyi ve bilince sahip midirler? Tüm bu soru/nları saydıktan sonra ailenin çocuğun eğitimi üzerindeki olumsuzluklarını gidermek için bazı önerilere yer verilebilir: Anne-baba başta birbirlerine sonra da çocuklarına karşı sorumluluklarının farkında olmalıdırlar. Bu bağlamda anne-baba eğitimi programlarına ve etkinliklerine ağırlık verilmelidir. Anne-babalar evvela çocuklarını anlama ve yönlendirme konusunda başarılı olabilmek için çocuk psikolojisini iyi bilmelidirler. Çocuklarının potansiyellerini, becerilerini, sorunlarını ve ilgilerini bilerek makul beklentiler içerisinde olmalıdırlar. Aile içerisinde yaşanan tüm sorunlar çocuğun yalnızca okuldaki başarısını değil, onun duygu dünyasını ve psikolojisini de olumsuz etkilemektedir. Bu sebeple aileler, çocukları üzerinde yaptıkları tahribatlar hususunda bilimsel verilerden de yararlanarak eğitilmeli ve bilinçlendirilmelidir. Ayrıca öğrencilerdeki başarısızlığının en büyük sebeplerinden biri de ebeveynlerin okula karşı ilgisizliğidir. Bu konuda okul-aile ilişkilerini daha sağlıklı hale getirebilmek için, sıkıcı veli toplantıları yerine daha işlevsel uygulamaların yürütülmesi gerekmektedir. Diğer yandan genel öğretim programları binişik bir formda olduğu için önceki öğrenmeler, daha sonraki öğrenmelerin temelini oluşturmaktadır. Bu sebeple ilköğretim seviyesinde istenen performansı gösteremeyen çocuk, büyük ihtimalle orta öğretim seviyesinde de beklenen başarıyı gösteremeyecektir. Bundan dolayı, çocukların eğitim süreçlerine okul öncesi dönemden başlayarak özen gösterilmelidir.

\subsection{Derse Olan İlgisizlik}

Öğretmenler ve yöneticiler, kimi öğrencilerin; derste işlenen konuya karşı dikkatlerini toplayamadıklarını, derse karşı ilgisiz olduklarını, derse hazırlıksız geldiklerini, derste farklı şeylerle ilgilendiklerini, zaman zaman motivasyonlarında düşüş olduğunu ifade etmektedirler ve bu öğrencileri ilgisizlikle yadırgamaktadırlar. Öneri noktasında bu tip öğrencilere yapabilecekleri sorumluluklar verilmeli ve sinıfta bir yerleri olduğu hissettirilmelidir. Bu tip öğrenciler, evlerinde de sevgi eksikliği olabileceği ihmalinden dolayı birkaç güzel söz söyleyerek motive edilmelidir. $\mathrm{Bu}$ bağlamda öğrencilerin gerekli ihtiyaçlarının karşılanması hususunda öğretmenlerin daha titiz davranması gerekir. Çünkü öğretmenlerin ve okul yöneticilerinin öğrencileri cesaretlendirici ve destekleyici bir tutum içerisinde olmaları ve öğrencilerle ilgilenmeleri, onların özgüven-özsaygı kazanmalarında etkili olabilir.

\section{Diğer Özellikler}

\subsection{Akran Zorbalığı}

Akran zorbalığı, öğrenciler arasında sık rastlanan şiddet davranışları arasında yer alır. Bunun önemli sebepleri arasında; arkadaşları üzerinde baskı kuran öğrencilerin böylece kendilerini arkadaşlarından daha güçlü ve 
üstün görmeleri, kurbanın gördüğü baskıyı/şiddeti hak ettiği düşüncesi ve şiddetin çözüm yolu olarak görülmesi yer almaktadır (Genç, 2007).

Akran zorbalığı konusunda yapılan tanımlar incelendiğinde; akran grupların birbirlerine karşı fiziksel, sosyal ya da sözel olarak kaba güç kullanması (Tani ve ark., 2003), bir grubun, bir gruba veya bireye devamlı uyguladı̆̆ gücün kötüye kullanılmasını içeren zarar verici davranışlar (Güvenir, 2004), birinin kendini savunamadığı halde başka kişi ya da kişilerin kendisine karşı doğrudan uyguladığı şiddetli davranışlar (Schuster, 1999) gibi farklı tanımlar olduğu görülmektedir. Bu tanımlar bağlamında zorba davranışları uygulayan ve bu davranışlara maruz kalan arasında güç dengesizliğinin bulunduğu, zorba davranışın sürekli ve bilinçli yapıldığı ve bu davranışların yıldırma amacı taşıması genel ölçütler arasında kabul edilmektedir.

Akran zorbalığına getirilebilecek bazı öneriler ise şöyledir: Okul yönetimi, rehber öğretmenler işbirliğiyle öğrencilerin maruz kaldıkları zorba davranışları belirlemek ve bunu engellemek amacıyla periyodik olarak anketler hazırlayarak sınıfın zorba davranış haritasını çıkartabilirler. Böylece okul yönetimi, RAM (Rehberlik Araștırma Merkezi) ile işbirliği yaparak devamlı zorba davranışlara maruz kalan bu öğrencilerin RAM'dan yardım alabilmeleri için öğrenci aileleriyle görüşebilir. Aynı zamanda okullarda devamlı zorba davranışlara maruz kalan bu öğrencilere rehberlik desteğinde "atılganlık eğitimi" verilip sosyal destek sağlanabilir. Ayrıca sınıf öğretmeni, işbirlikli öğrenmeye önem vererek zorbalığa eğilimli öğrencileri sosyal faaliyetlere ve grup çalışmalarına yönlendirebilirler (Çankaya, 2011).

\section{2. Öğrencilerin Araç Gereçleri Getirmemesi}

Öğrencinin, sorumsuzluğuna bağlı olarak bazen sınıfta kullanması gereken araç-gereçleri sınıfa getirmediği veya getirdiği halde kullanmadığı görülür. Bunun çok farklı nedenleri olabilir. Bu nedenlerden bazlları arasında; öğrencilerin vurdumduymazlıkları, unutkanlıkları ya da maddi olarak bu araç-gereçleri temin etmede güçlük yaşamaları sayılabilir. $\mathrm{Bu}$ noktada öğretmenin yapması gereken, öğrencinin bu konudaki eksikliğinin sebebini öğrenip gerekirse okul rehber öğretmeni ve veli ile de görüşüp sebebe bağlı olarak eşgüdümlü bir çözüm yolu getirmektir.

\section{Sonuç Tartışma ve Öneriler}

Yapılan literatür taraması sonucu, öğrencilerden kaynaklanan istenmeyen davranışların bazılarının bireysel nedenlerden bazılarının da sosyo-kültürel nedenlerden kaynaklanan problemler olduğu görülmektedir. Bununla birlikte bazı problemlerin eğitim-öğretim süreçleri ile aza indirilebilir olduğu dikkate alındığında bu konularda öğrencilerin yanı sıra okul idarecilerinin, ebeveynlerin ve ailelerin eğitilmesinin sorunların üstesinden gelinmesinin anahtarı olacağı söylenebilir. Sezer ve İşgör (2010) bu konuda ailelerin katılımını da kapsayacak şekilde gerçekleştirilecek 
gelişimsel rehberlik eksenli faaliyetlerin yürütülmesine öncelik verilmesi gerektiği vurgulamaktadır. Bu sebeple sık sık istenmeyen davranış sergileyen öğrencilere gerekli psikolojik desteğin sağlanması faydalı olacaktır. Bunun nedenlerinin belirlenmesi, okul iş görenlerinin bu hususlarda da eğitilmesi ve ailelere de bu eğitimlerin verilmesi yararlı olacaktır.

Ayrıca yapılan çalışmalarda öğrencilerin okula hazırbulunuşluğu konusunda okul öncesi eğitimin büyük önem taşıdığı görülmüştür. Bu durumu kendi içinde etkileyen fiziki ve eğitsel faktörler de bulunmaktadır. Bununla birlikte öğrencilerin öğretmen, akran ve çevre ile olan ilişkilerinde gerçekleșen iletişim sorununun da konumuz açısından karşılaşılan sorunlar çerçevesinde etkili olduğu görülmektedir. Çünkü sağlıklı bir iletişim için bireylerin kaynak ve hedef arasındaki süreci doğru ve etkili bir şekilde gerçekleştirmeleri gerekmektedir. Bu sürecin kusurlu veya verimsiz bir şekilde gerçekleşmesi sonucunda verilmek istenen mesajın yanlış ifade edilmesi ya da yanlış anlaşılması gibi durumları ortaya çıkardığı görülmüștür.

Kaygı düzeyinin de toplumsal alanda etkili olduğu bilinmekle beraber öğrenciler açısından özellikle sınav kaygısının olumsuz bir sonuç ortaya çıkardığı anlaşılmaktadır. Öğrenciler açısından karşılaştığımız bir diğer problem ise dikkat dağınıklığı olarak karşımıza çıkmıştır. Fakat yapılan çalışmalarda bunu aşabilmenin mümkün olduğu ifade edilmiştir. Öğrencilerin derse karşı ön yargılı olmalarının ise hem odaklanma sorunu oluşturduğu hem de öğretim açısından büyük bir probleme neden olduğu görülmektedir.

Öğrencinin kişisel gelişiminin en önemli faktörlerinden birisinin kitap okuma alışkanlığı olduğu ifade edilmektedir. Öğrencilerin kitap okuma alışkanlıklarının olmaması bu noktada karşılaşılan sorunlardan birini oluşturmaktadır. Bunlarla beraber rekabetin de dengesiz beceri gelişimine yol açtığı görülmüştür.

Eğitimin gerçekleştiği ilk kurum olarak ifade edilen ailedeki iletişimin sorunlu olması, okulda gerçekleşecek olan eğitimin de sorunlu olmasını beraberinde getirir. Bununla birlikte, öğrencilerin başarısızlıklarının en mühim nedenlerinden biri de ebeveynlerin okula ve okul hayatına karşı ilgisizlikleridir. $\mathrm{Bu}$ sorunun temelini ise öğrencilerin isteklerinin ve kapasitelerinin aileler tarafından bilinmemesinin oluşturduğu görülmektedir. Tüm bunlarla birlikte birbiriyle ilişkili bir süreç olarak öğrencilerin derse karşı ilgisizlikleri de önemli sorunlardan birisi olarak karşımıza çıkmaktadır.

Tüm bunlarla beraber akran zorbalığı ve öğrencilerin materyal sorumsuzluğu da karşılaşılan öğrenci kaynaklı sorunlar olarak ifade edilebilir. Özellikle temel eğitim aşamasında karşılaşılan öğrenci kaynaklı 
problemlere karşı aşağıdaki önerilerin dikkate alınması, bu problemleri en aza indirmenin bir yolu olarak düşünülmektedir.

1. Okul öncesi eğitimde hazır bulunuşluk üzerine yapılan çalışmalar dikkate alınmalı.

2. Öğrenci, öğretmen, aile ve çevre iletişimini sağlıklı hale getirmeli.

3. Kaygı düzeylerinin ölçülmesi adına öğrencilerle çalışmalar yapılmalı ve sonuçlar ışığında bu durumu en aza indirmek için çözümler ortaya konmalı.

4. Öğrencileri derse bağlayacak etkinlikler düzenlenmeli.

5. Öğrencilerde kitap okuma alışkanlığı kazandırmak adına bu uygulama özellikle ailelerde başlatılmalı.

6. Tüm bunlar için en önemli ve etkili çözüm olarak aileler bilinçlendirilmeli.

\section{KAYNAKÇA}

Bekman, S. - Aksu Koç, A. - Erguvanlı Taylan, E.- Vakfı, A. Ç. E. (2004). Güneydoğu Anadolu Bölgesi'nde bir erken müdahale modeli: Yaz anaokulu pilot uygulaması. Boğaziçi Üniversitesi ve Anne-Çocuk Eğitim Vakfi, 20 (10), 2014.

Clifford, M. M. (1989). Competition: can the assets exceed the liabilities?. New Designs for Youth Development Journal, 1 (3), 25-30.

Çankaya, İ. (2011). İlköğretimde akran zorbalığı. Uludağ Üniversitesi Eğitim Fakültesi Dergisi, 24 (1), 81-92.

Çoban, A. (2016). Türkçe eğitimi ve öğretiminin sorunları. Littera Turca Journal of Turkish Language and Literature, 2 (1), 121-138.

Demirtaş, E. (1999). Sinemanın bir iletişim biçimi olarak tüketilmesi - Örnek olay inceleme: Titanic" batan gemi sinemayl kurtardı mı?. İstanbul: Marmara Üniversitesi Sosyal Bilimler Enstitüsü Yayımlanmamış Yüksek Lisans Tezi.

Deniz, E. (2015). Ortaokul öğrencilerinin kitap okuma alışkanlıkları / Reading habits of secondary school students. Okuma Yazma Ĕgitimi Araştırmaları, 3 (2), 46-64.

Dökmen, Ü. (1994). Okuma becerisi, ilgisi ve alışkanlı̆̆ı üzerine psiko-sosyal bir araştırma. Ankara: Milli Eğitim Bakanlığı.

Gencer, Ö. (2009). Eğitim fakülteleri Alman dili eğitimi anabilim dalı derslerinde yabancı kültürle karşslaşma ve önyargılar ampirik - nitel bir araştırma. Çanakkale: Çanakkale Onsekiz Mart Üniversitesi Sosyal Bilimler Enstitüsü Yayımlanmamış Yüksek Lisans Tezi.

Erkan, S. - Kırca, A. (2010). Okul öncesi eğitimin ilköğretim birinci sınıf öğrencilerinin okula hazırbulunuşluklarına etkisini incelenmesi. Hacettepe Üniversitesi Eğitim Fakültesi Dergisi, 38 (38), 94-106.

Genç, G. (2007). Genel liselerde akran zorbalı̆ğ ve yönetimi. Malatya: İnönü Üniversitesi Sosyal Bilimler Enstitüsü Yayımlanmamış Doktora Tezi.

Göğüş, B. (1983). “Okumayı biliyor muyuz?” Öğretmen Dünyası Dergisi, 44, 7-9.

Güvenir, T. (2004). Okulda akran istismarı. Ankara: Kök. 
İnan, D. D. (2005). İlköğretim I. kademe öğrencilerinin okuma alışkanlıklarının incelenmesi. İstanbul: Marmara Üniversitesi Eğitim Bilimleri Enstitüsü Yayımlanmamış Yüksek Lisans Tezi.

Küçükahmet, L. (2004). Hayat bilgisi programının değerlendirilmesi. Eğitimde Yansımalar: VIII Yeni İlköğretim Programlarını Değerlendirme Sempozyumu, 373-381.

Mert, E. L. (2014). Türkçe öğretmeni adaylarının okuma ilgi düzeylerinin farklı değişkenler açısından incelenmesi. Turkish Studies, 9 (3), 959-968.

Nuhoğlu, M. M. - Karakuş, E. - Taş, H. (2007). Türkçe öğretimi etkinlikleri. Ankara: Nobel.

Palti, C. (2012). Üniversiteye hazırlanan lise son sınıf öğrencilerinde yükseköğretime geçiș sınavı öncesi ve sonrasında benlik Saygısı, sinav kaygısı ve durumluk-sürekli kaygı düzeyleri. İstanbul: İstanbul Üniversitesi Sosyal Bilimleri Enstitüsü Yayımlanmamış Yüksek Lisans Tezi.

Schuster, B. (1999). Outsiders at school: the prevalence of bullying and its relation with social status group. Processes and Intergroup Relations, 2 (2), 175-190.

Sezer, F. - İşgör, İ. Y. (2010). İlköğretim ve ortaöğretim kurumlarındaki öğrencilerin problem alanlarının tespiti (Erzurum ili örneği). Milli Eğitim, 39 (186), 235248.

Sillars, A. L. (1995). Communication and family culture. Explaining Family Interactions, 375-399.

Sönmez, V. - Alacapınar, F. (2013). Örneklendirilmiş bilimsel araștırma yöntemleri. Ankara: Anı.

Spielberger, C. D. (1972). Review of profile of mood states. 3-20.

Tani, F. - Paul, S. - Greenman, B. H. - Schneider, F. (2003). Bullying and the big five: A study of childhood personality and participant roles on bullying incidents. School Psychology International, 24 (2), 131- 146.

Topses, G. (2003). Gelişim ve öğrenme psikolojisi. Ankara: Nobel.

Yavuzer, H. (2001). Çocuk psikolojisi. İstanbul: Remzi Kitabevi.

“Iyi Yayın Üzerine Kılavuzlar ve Yayın Etiği Komitesi'nin (COPE) Davranış Kuralları” çerçevesinde așağıdaki beyanlara yer verilmistir. / The following statements are included within the framework of "Guidelines on Good Publication and the Code of Conduct of the Publication Ethics Committee (COPE)":

İzinler ve Etik Kurul Belgesi/Permissions and Ethics Committee Certificate: Makale konusu ve kapsamı etik kurul onay belgesi gerektirmemektedir. / The subject and scope of the article do not require an ethics committee approval.

Çıkar Çatışması Beyanı/Declaration of Conflicting Interests: Bu makalenin araştırması, yazarlığı veya yayınlanmasıyla ilgili olarak yazarın potansiyel bir çıkar çatışması yoktur. / There is no potential conflict of interest for the author regarding the research, authorship or publication of this article. 